\title{
Homozygous 4.1(-) Hereditary Elliptocytosis Associated with a Point Mutation in the Downstream Initiation Codon of Protein 4.1 Gene
}

\author{
N. Dalla Venezia, * F. Gilsanz, * N. Alloisio, * M.-T. Ducluzeau, * E. J. Benz, Jr.," and J. Delaunay * \\ *Centre National de la Recherche Scientifique Unité de Recherche Associée 1171, Faculté de Médecine Grange-Blanche, 69373 Lyon \\ Cedex 08; Institut Pasteur de Lyon, 69365 Lyon Cedex 07, France; ${ }^{\ddagger}$ Hematologia, Hospital "12 de Octubre," \\ Universidad Complutense, Madrid 28041, Spain; and ${ }^{\S}$ Hematology Section, Department of Internal \\ Medicine and Human Genetics, Yale University School of Medicine, New Haven, Connecticut 06510
}

\begin{abstract}
We studied a 43 yr-old Spanish patient with homozygous 4.1 ( - ) hereditary elliptocytosis. Any form of protein 4.1 was missing in the red cells. Spectrin and actin were slightly, yet significantly, diminished. Alterations appeared at the level of proteins 4.5 and 4.9. Glycophorin $C$ was sharply reduced. The abnormal allele was associated with the -++-- haplotype (Pvu II, Bgl II, Bgl II, Pvu II, Pvu II). mRNA 4.1 (-) had an apparently normal size but was diminished by about two-thirds. Because the abnormal phenotype pertained to the red cell, we sequenced the 4.1 cDNA regions that appear critical to this cell type. The ultimate change turned out to be a point mutation of the downstream translation initiation codon (AUG $\rightarrow$ AGG). No disorders in other cell types could be related with certainty to the present 4.1(-) HE allele. (J. Clin. Invest. 1992. 90:1713-1717.) Key words: 4.1(-) hereditary elliptocytosis • initiation codon $\bullet$ point mutation
\end{abstract}

\section{Introduction}

Protein 4.1 is a $80-\mathrm{kD}$ protein that belongs to the red cell skeleton (For reviews, see references 1 and 2). In vitro proteolysis has allowed to dissect protein 4.1 into four domains of 30,16 , 10 , and $22 / 24 \mathrm{kD}$, respectively (3). It is phosphorylated (4-7) and glycosylated $(8,9)$. Protein 4.1 occurs as 200,000 copies per erythrocyte. Through its $10-\mathrm{kD}$ domain, it participates in the interaction between actin and spectrin. These proteins, as well as others, assemble to form the junctional complex (2, 10). Protein 4.1 is connected to transmembrane proteins by its $30-\mathrm{kD}$ domain $(11,12)$. The sequence of erythroid protein 4.1 has been deduced from cDNA 4.1 (13-15).

Protein 4.1 gene exists as one copy per haploid genome and maps to $1 \mathrm{p} 33 \rightarrow \mathrm{p} 34.2(16,17)$. Its structure is partially known at this time. In the French population, it was found to be associated with five different haplotypes involving the following polymorphic sites-Pvu II, Bgl II, Bgl II, Pvu II, Pvu II-that have been tentatively aligned in this order (18). A Hind III

Address reprint requests to Dr. Dalla Venezia, Génétique Moléculaire Humaine, CNRS URA 1171, Faculté de Médecine Grange-Blanche, 69373 Lyon Cedex 08, France.

Received for publication 3 February 1992 and in revised form 19 May 1992.

J. Clin. Invest.

(c) The American Society for Clinical Investigation, Inc.

$0021-9738 / 92 / 11 / 1713 / 05 \quad \$ 2.00$

Volume 90, November 1992, 1713-1717 polymorphism was described in the Chinese population (19). Immunological studies have long indicated that protein 4.1 is present as isoforms in a number of cell types. Some of these isoforms are spliceoforms. They result from complex splicing pathways that concern tissue- and development-specific alternative motifs $(20,21)$. Two initiation codons exist. They will be referred to as upstream and downstream. Late erythroid cells use the latter one, exclusively.

4.1 (-) hereditary elliptocytosis (HE) ${ }^{1}$ designates a condition in which the red cell protein 4.1 is reduced (heterozygous state) or absent (homozygous state). Heterozygous 4.1 (-) HE is a clinically silent, dominantly transmitted condition (2224). Homozygous 4.1(-) HE is exceptional. It has been described in three children of Algerian family BR $(25,26)$ and in an American child (27). The absence of protein 4.1 is accompanied by a sharp reduction of transmembrane glycophorin $\mathrm{C}$ (GPC) (27-30). This observation is the strongest evidence that protein 4.1 stabilizes glycophorin $C$ in the membrane.

Combining haplotypes and mRNA patterns, several 4.1 (-) HE alleles have been outlined $(16,18)$, but no genomic lesion has been identified thus far. One pending question is how nonerythroid cell types, that look normal in the heterozygous and even in the homozygous states as far as is known, do manage the consequences of the 4.1 (-) HE alleles.

A novel 4.1(-) HE allele, designated allele 4.1 Madrid, is reported in the homozygous state. It carries a point mutation in the downstream initiation codon. Apparently, clinical manifestations spare most tissues except for the red cells.

\section{Case report}

The propositus, designated member II. 9 of family SA, was born in 1948 in Fuentes de Ropel (Zamora Province, northwestern Spain). His parents were second cousins. Since birth, he has had intermittent jaundice and pallor. In 1979, the proband displayed an aplastic crisis. Spleen was felt $10 \mathrm{~cm}$ below the coastal margin. The red cell indices were: $R B C 2.06 \times 10^{12} /$ liter; hemoglobin $50 \mathrm{~g} /$ liter; mean corpuscular volume $77 \mathrm{f} \mathrm{L}$; reticulocytes $350 \times 10^{9} /$ liter $(17 \%)$. Some transfusions were performed. Splenectomy, performed in 1979 and combined with cholecystectomy due to gallstones, yielded a remarkable hematological improvement. Blood smears disclose anisocytosis, poikilocytosis with elliptocytosis, and fragmented erythrocytes (not shown). Patient II.9 displays an infertility associated with azoospermia and a right ureterocele. The propositus's mother is healthy, although her blood smears show elliptocytosis

1. Abbreviations used in this paper: GPC and GPD, glycophorins $C$ and D; HE, hereditary elliptocytosis; nt, nucleotide; PCR, polymerase chain reaction. 


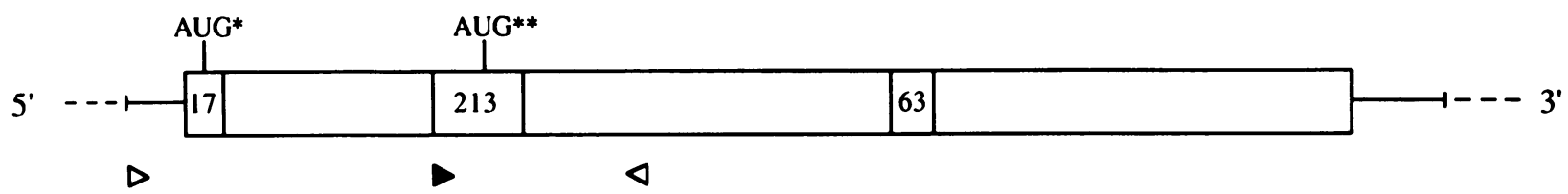

Figure 1. Schematic representation of $4.1 \mathrm{mRNA}$. AUG* and $\mathrm{AUG}^{* *}$, upstream and downstream translation initiation codons, respectively; $\triangleright$ and $\triangleleft$, amplification primers A and B, respectively; $\bullet$, sequencing primer C. Size of alternative sequences are given in nucleotides. 17-nt sequence and 63-nt exon are named motifs IV and I, respectively.

(4.1(-) HE in the heterozygous state). We lack data on the propositus's father, deceased.

\section{Methods}

Protein analysis. Preparation of erythrocyte ghosts was carried out as described before (22). Proteins were resolved by SDS-PAGE $(31,32)$. The amounts of protein 4.1 and of other proteins was determined by densitometry at $570 \mathrm{~nm}$ after Coomassie blue staining $(22,33)$. Protein 4.1 was also studied using Western blots (18). Spectrin dimer self-association was determined (34). Glycophorins were resolved using SDS-PAGE (31) and stained by silver technique (29).

Haplotype analysis. DNA was extracted from peripheral blood leukocytes and digested with several restriction endonucleases ( Pvu II, Bgl II). Southern blots were performed using two random primed 4.1 cDNA probes ( $\mathrm{pLym} 5^{\prime}$ and pLym $3^{\prime}$ ) resulting from a Bam HI digestion of a lymphoid cDNA 4.1 clone designated pLym $(18,20)$.

4.1 mRNA analysis. Reticulocyte mRNA 4.1 was studied by Northern blot and dot blot analysis using the pLym 5' and pLym 3' probes as previously described (18). As an internal standard for dot blots, we used the signal yielded by an $\alpha$-globin 1.5-kb Pst I fragment (35). Serial amounts of mRNA were applied. After hybridization, autoradiograms were analyzed by densitometry. To normalize the results with respect to the conditions of subsequent hybridizations with pLym 5 ' and pLym 3 ', respectively, we calculated for each series of dots the mean of the optical density ratios: $P_{5^{\prime}} / C_{5^{\prime}}$ and $P_{3^{\prime}} / C_{3^{\prime}}$ (P, patient II.9; C, control; $5^{\prime}$, pLym 5'; 3', pLym $\left.3^{\prime}\right)$. In order also to standardize the results with respect to the genuine amount of $m R N A$ applied in each case ( $P$ or $C$ ), we expressed the level of mRNA 4.1 as follows:

$\frac{P_{5^{\prime}} / C_{5^{\prime}}}{P_{\alpha} / C_{\alpha}}$ and $\frac{P_{3^{\prime}} / C_{3^{\prime}}}{P_{\alpha} / C_{\alpha}}$

( $P_{\alpha}$ and $C_{\alpha}$ : optical densities measured using the $\alpha$-globin probe).

cDNA sequencing. We focused on erythroid specific regions of mRNA 4.1. Reverse transcription (RT) was carried out essentially according to Kawasaki (36) and Frohman et al. (37). Using the polymerase chain reaction (PCR), we amplified the cDNA segments encoding motif I (20) (primers not shown) and the 213-nucleotide (nt) motif that carries the downstream initiation codon (21). In the latter case, PCR was carried out with primers A (sense): GC(GAATTC)GTGGAGCAGAGGGGCAAAGT, and B (antisense): GC(GAATTC)AACTGTGCTGGGTCAGGTGG (Fig. 1), as described or referred elsewhere (38). Specifically, 30 cycles were performed: denaturation $\left(92^{\circ} \mathrm{C}, 60 \mathrm{~s}\right)$, annealing $\left(62^{\circ} \mathrm{C}, 30 \mathrm{~s}\right)$ and extension $\left(72^{\circ} \mathrm{C}, 60\right.$ s). Direct sequencing was done as previously described or referred to (38), using primer C (sense): AAGGAAGGAGAAGGACT (Fig. 1).

Restriction mapping. A genomic DNA fragment of the 213-nt motif was PCR-amplified using primers D (sense): GCTCAGGAAGAACTCAGAGA, and E (antisense): TCCACAACACATTCATAAACTG. 30 cycles were performed: denaturation $\left(92^{\circ} \mathrm{C}, 60 \mathrm{~s}\right)$, annealing $\left(56^{\circ} \mathrm{C}, 30 \mathrm{~s}\right)$ and extension $\left(72^{\circ} \mathrm{C}, 60 \mathrm{~s}\right)$. The 209-bp fragment obtained was digested with Nla III. The subfragments were monitored using 5\% Nusieve GTG agarose (FMC Bioproducts, Rockland, ME) gel electrophoresis and ethidium bromide staining.

\section{Results}

Protein analysis. (a) SDS-PAGE revealed the absence of protein 4.1 in individual II.9 (Fig. 2). Western blots using antiprotein 4.1 polyclonal antibodies confirmed the lack of protein 4.1 (Fig. 2). No abnormal band 4.1 was recorded. In addition, protein overload $(80 \mu \mathrm{g}$ ) revealed no obvious $135-\mathrm{kD}$ isoform of protein 4.1 , in the patient nor in a control, even though this component is present in the erythroblasts in a punctate pattern (39). (b) The amounts of spectrin $\alpha$ - and $\beta$-chains and of actin were slightly, but significantly reduced (data not shown). The amount of protein 4.2 was at the lower limit of normal values (data not shown). (c) A $55-\mathrm{kD}$ protein was missing in the region of band 4.5 (Fig. 2). (d) Protein 4.9 was duplicated (Fig. 2). (e) Glycophorins $C$ and D were sharply diminished. Altogether, these data confirmed and extended previous results (27-30). On the contrary, spectrin self-association parameters were within normal range (data not shown).

In a $4.1(-)$ heterozygote (member II.4, a cousin of the propositus on his paternal side), protein 4.1 was decreased by $15 \%$, conforming to values (lower limit) found in previous studies $(18,22)$.

Haplotype analysis. The haplotype associated with the absence of erythroid protein 4.1 in individual II.9 was -++-for the enzymes Pvu II, Bgl II, Bgl II, Pvu II, and Pvu II, respectively. This haplotype was found in the homozygous state.

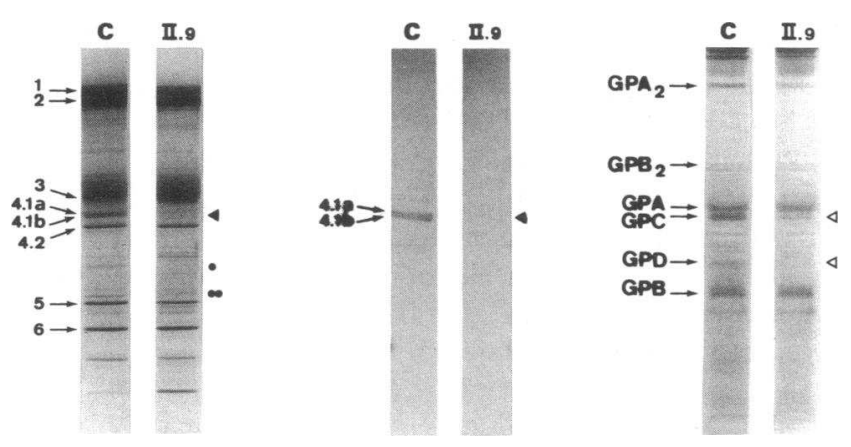

Figure 2. Protein analysis in patient II.9. Left: SDS-PAGE (acrylamide concentration $7 \%$ ) and Coomassie Blue staining. 4, absence of protein 4.1 ; •, absence of a $55-\mathrm{kD}$ protein (region of band 4.5 ); protein $4.1 ; \bullet$, absence of a $55-\mathrm{kD}$ protein (region of band 4.5 ); $\bullet \bullet$, duplication of protein 4.9. Middle: Western blots using polyclonal antiprotein 4.1 antibodies. In addition to a major band ( $80 \mathrm{kD})$, two minor bands ( 86 and $69 \mathrm{kD}$ ) were visible in the control. Right: SDSPAGE (acrylamide concentration 15\%) and silver staining of glycophorins (GP). $\triangleleft$, reduction of glycophorins $C$ and D. 


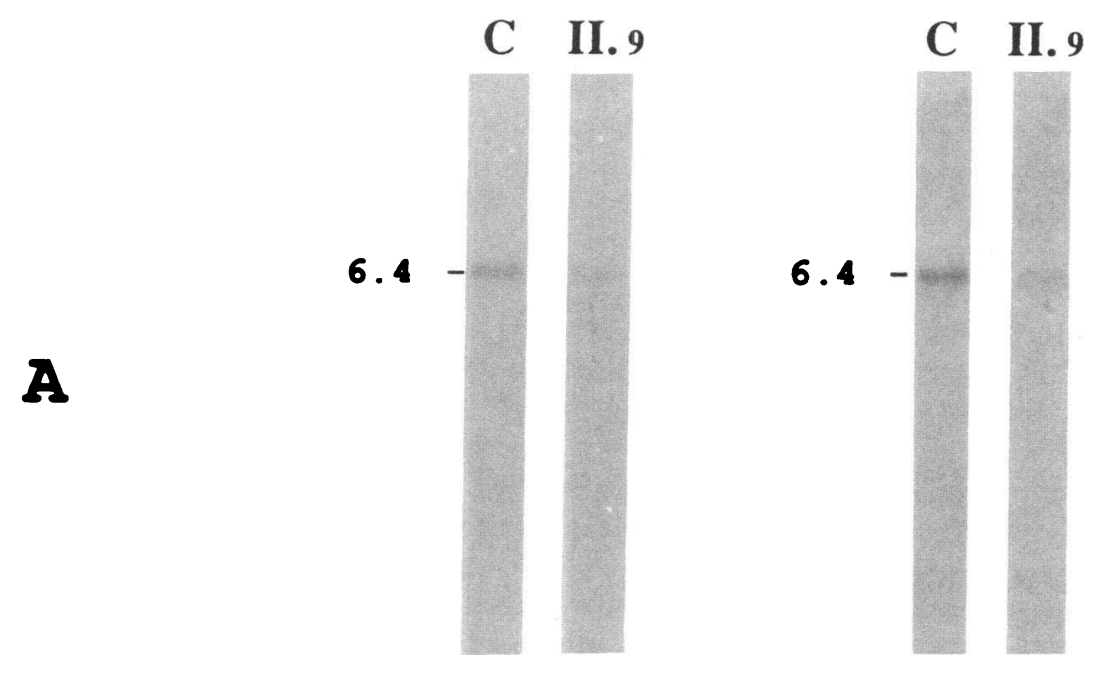

B

pLym 5'

pLym 3'

$\alpha-$ globin
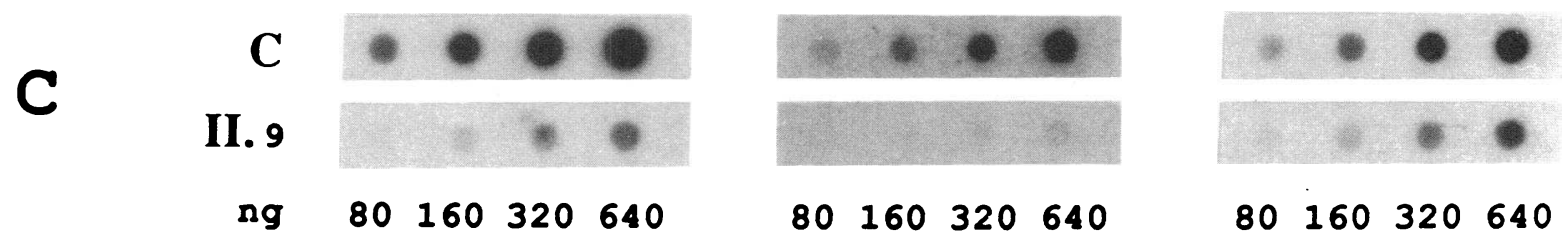

Figure 3. Northern blot and dot blot analysis. (A) Northern blot analysis; the band size is given in kilobases. (B) cDNA probes. (C) Dot blot analysis; serial dilutions of reticulocyte RNA are indicated; $\alpha$-globin $1.5 \mathrm{~kb}$ Pst I fragment was used as an internal standard probe.

$m R N A 4.1$ analysis. Northern blot analysis allowed to visualize mRNA 4.1 in reticulocytes using both probes pLym $5^{\prime}$ and pLym 3'. It appeared with a normal size and a reduced amount (Fig. 3). Dot blot analysis, using an $\alpha$-globin probe as internal standard (18), indicated that the amount of mRNA 4.1 was uniformly reduced by $63 \%$ (pLym $5^{\prime}$ ) and $62 \%$ (pLym $3^{\prime}$ ) with respect to mRNA 4.1 from a control (Fig. 3). Such a
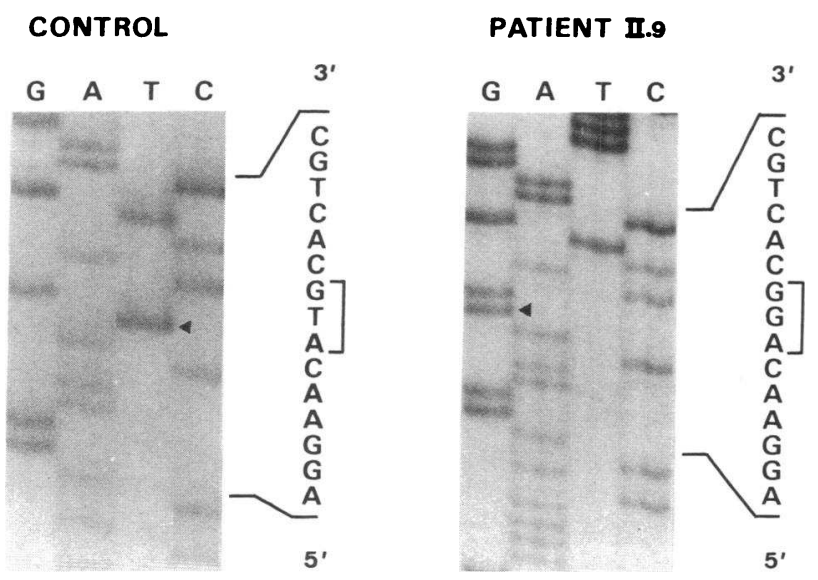

Figure 4. Sequencing of cDNA 4.1 in patient II.9. Reverse transcription PCR was carried out with primers $A$ and $B$. Partial sequence of the 990 -bp fragment is shown. $4, \mathrm{~T}$ to $\mathrm{G}$ substitution in patient II.9.
mRNA pattern has never been found before in association with a 4.1(-) HE allele.

DNA sequence study. Because the symptomatology was essentially restricted to the red cells, we focused on two cDNA regions which appear critical to this cell type, namely motif I and the downstream initiation codon. The sequence of motif I was normal (data not shown). After RT-PCR amplification of 4.1 mRNA around the downstream initiation codon, a prevalent fragment of $990 \mathrm{bp}$ was obtained, corresponding to the major mRNA 4.1 erythroid isoform (21). Sequencing, carried

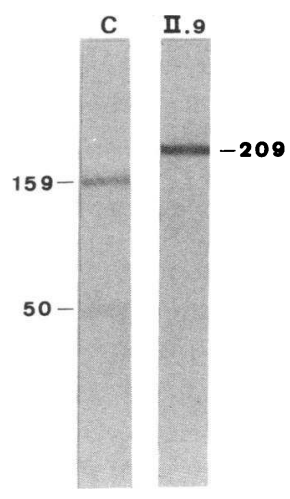

Figure 5. Nla III restriction map of DNA fragment in patient II.9. PCR was carried out with primers $\mathrm{D}$ and E. Digestion by Nla III endonuclease of the 209-bp fragment is shown. The Nla III site is abolished in Nla III patient II.9. 
out after an additional set of (asymetrical) PCR, showed a T to G substitution (AUG $\rightarrow$ AGG) at the position 161 of the 213nt exon (21) (Fig. 4). Therefore, the downstream AUG initiation codon appeared closed.

This substitution abolished a Nla III site. Accordingly, we PCR-amplified the genomic DNA in patient II. 9 and in a control (primers D/E). The resulting 209-bp fragment was digested with Nla III. Two bands of the expected sizes (159 bp and $50 \mathrm{bp}$ ) were observed in the control. In patient II.9, the 209-bp band expectedly appeared undigested (Fig. 5).

Altogether, the simple base mutation (ATG $\rightarrow$ AGG) found in protein 4.1 gene, along with the above RFLPs, defines a new allele that we designated allele 4.1 Madrid.

\section{Discussion}

We have described the third independent case of $\mathrm{HE}$ associated with the absence of erythroid protein 4.1. The patient presented by Mueller and Morrison (27) having not been investigated in detail, we will refer mainly to the three genuine homozygous sisters recognized in Algerian family $\operatorname{BR}(25,26)$.

Owing to his age, individual II.9 provides further information as regards the evolution of homozygous 4.1(-) HE. A period of $31 \mathrm{yr}$ elapsed before splenectomy with manifest clinical symptoms, but only a few transfusions. This evolution, along with that recorded in the three $4.1(-)$ homozygotes of Algerian family BR $(25,26)$ (Prof. G. Tchernia, personal communication), shows that homozygous $4.1(-)$ HE is considerably alleviated by splenectomy, but that this operation can be avoided in the early life.

The biochemical phenotype of the proband was strictly superimposable to that observed in family $\operatorname{BR}(25,26,28)$. Clearly, the primary lack of protein 4.1 yields a dramatic disruption of the junctional complex. All the local changes would be worth being examined in greater detail so as to unravel the protein interactions within the complex.

Allele 4.1 Madrid, nonetheless, departs from other 4.1(-) alleles. In Algerian family BR, the data presented outline aberrant restriction patterns as regards Pst I, EcoR I, and Pvu II sites and the existence of an abnormally spliced mRNA 4.1 (16). (It appears that the BglII pattern pertains to the presence of polymorphic site $b$ described subsequently [18]). In French families, two additional 4.1 ( - ) alleles have been defined on the basis of distinct haplotypes and mRNA patterns (18). We come to the idea that $4.1(-)$ HE alleles are highly heterogeneous.

The mutation characterizing allele 4.1 Madrid takes place in an exonic sequence. Accordingly, it is expressed as long as this sequence is not skipped. It is unknown whether the 213-nt motif undergoes prevalent skipping in some tissues. It seems likely, however, that the downstream initiation codon is utilized significantly in many cell types. Under this assumption, homozygosity for allele 4.1 Madrid is informative about the role of $80-\mathrm{kD}$ protein 4.1. Apparently, no obvious disorder was noted in patient II.9 outside the red cells and, tentatively, the germ cells (see below). It looks as if the spliceoforms $(\sim 135$ $\mathrm{kD}$ ), arising from the use of the upstream initiation codon, compensate for spliceoforms $(\sim 80 \mathrm{kD})$, arising from the use of the downstream initiation codon $(40,41)$. (The presence of the Met $\rightarrow$ Arg substitution at position 109 of the $\sim 135-\mathrm{kD}$ spliceoform(s) would have no or little effect). In the erythroid cell line, however, the splicing out of motif IV, removing upstream initiation codon $(20,21)$, leaves the cells devoid of any compensatory supply of protein 4.1 . We may speculate that a similar situation would apply to the sperm cells or their precursors, and account for azoospermia. Yet, we cannot rule out another cause and, in particular, the homozygosity for another deleterious allele.

Whereas heterozygous 4.1(-) HE accounts for one fourth to one third of total HE in Caucasians, in our experience, the incidence of homozygous 4.1(-) HE probably remains lower than expected. We hypothesize that some 4.1(-) HE alleles must not be viable in the homozygous state because they would affect the 135 - and the $80-\mathrm{kD}$ isoforms at a time. For example, a stop codon $3^{\prime}$ of the downstream initiation codon (and in an unskipped exon) would leave all cells short of protein 4.1.

To our knowledge, the present mutation is the first genomic change to be recognized in association with a protein 4.1 abnormality. The mutations of other $4.1(-)$ alleles $(16,18)$ remain elusive. They seem to act through abnormal splicing. One may anticipate that their tissue-specific expression depends on how the responsible mutations interfere with local trans-factors. In the case of the 4.1(-) HE allele of Algerian family BR, skipping of the 213-and 105-nt exons occurs in erythroid cells, but also in fibroblasts (41). Other splicing mutations result in the redistribution of spliceoforms at the benefit of minor species (42, 43; Feddal, S., et al., manuscript submitted for publication).

The present mutation correlates with a decrease of approximatively $60 \%$ in the level of mRNA. Similarly, initiation codon mutations in $\alpha_{1}$ - and $\alpha_{2}$-globin genes have been found associated with a three- to fourfold decrease in the level of corresponding mRNA $(44,45)$. Nonsense mutations in $\beta$-globin gene affect mRNA metabolism to a comparable extent (46). One possible explanation would be the enzymatic degradation in the cytoplasm of a mRNA which is not translated at all or is translated over a short segment. Another explanation would invoke nuclear events. A feedback signal raised from absent or partial translation could inhibit mRNA transport out of nucleus. Further work will be needed in order to clarify these issues.

In this work, we have presented allele 4.1 Madrid, a unique 4.1 allele responsible for $4.1(-) \mathrm{HE}$ and carrying a point mutation in the downstream initiation codon. Whereas allele 4.1 Madrid is deleterious to the red cell in the homozygous state, the upstream initiation codon apparently spared the synthesis of $135-\mathrm{kD}$ protein in other cell types.

\section{Acknowledgments}

We thank family SA for their kind cooperation, Mrs. E. Salinas for her help in collecting samples, and Pr. G. Tchernia for communicating some clinical data on another family with homozygous 4.1(-) HE.

This work was supported by the Association Française contre les Myopathies, the Universite Claude-Bernard Lyon-I, the Institut Pasteur de Lyon, the Centre National de la Recherche Scientifique (URA 1171 ), and the Caisse Nationale d'Assurance Maladie des Travailleurs Salariés (Grant 8969 002).

\section{References}

1. Bennett, V. 1989. The spectrin-actin junction of erythrocyte membrane skeletons. Biochim. Biophys. Acta. 988:107-121. 
2. Delaunay, J., N. Alloisio, L. Morlé, and B. Pothier. 1990. The red cell skeleton and its genetic disorders. Mol. Aspects Med. 11:161-241.

3. Leto, T. L., and V. T. Marchesi. 1984. A structural model of human erythrocyte protein 4.1. J. Biol. Chem. 259:4603-4608.

4. Horne, W. C., T. L. Leto, and V. T. Marchesi. 1985. Differential phosphorylation of multiple sites in protein 4.1 and protein 4.9 by phorbol ester-activated and cyclic AMP-dependent protein kinases. J. Biol. Chem. 260:9073-9076.

5. Cohen, C. M., and S. F. Foley. 1986. Phorbol ester- and $\mathrm{Ca}^{2+}$-dependen phosphorylation of human red cell membrane skeletal proteins. J. Biol. Chem. 261:7701-7709.

6. Danilov, Y. N., R. Fennell, E. Ling, and C. M. Cohen. 1990. Selective modulation of band 4.1 binding to erythrocyte membranes by protein kinase $C$. J. Biol. Chem. 265:2556-2562.

7. Subrahmanyam, G., P. J. Bertics, and R. A. Anderson. 1991. Phosphorylation of protein 4.1 on tyrosine-418 modulates its function in vitro. Proc. Natl. Acad. Sci. USA. 88:5222-5226.

8. Holt, G. D., R. S. Haltiwanger, C. R. Torres, and G. W. Hart. 1987. Erythrocytes contain cytoplasmic glycoproteins: $O$-linked GlcNAc on band 4.1. J. Biol. Chem. 262:14847-14850.

9. Inaba, M., and Y. Maede. 1989. O-N-Acetyl-D-glucosamine moiety on discrete peptide of multiple protein 4.1 isoforms regulated by alternative pathway. J. Biol. Chem. 264:18149-18155.

10. Liu, S. C., L. H. Derick, and J. Palek. 1987. Visualization of the hexagonal lattice in the erythrocyte membrane skeleton. J. Cell Biol. 104:527-536.

11. Anderson, R. A., and V. T. Marchesi. 1985. Regulation of the association of membrane skeletal protein 4.1 with glycophorin by a polyphosphoinositide. Nature (Lond.). 318:295-298.

12. Pasternack, G. R., R. A. Anderson, T. L. Leto, and V. T. Marchesi. 1985 Interactions between protein 4.1 and band $3:$ an alternative binding site for an element of the membrane skeleton. J. Biol. Chem. 260:3676-3683.

13. Conboy, J., Y. W. Kan, S. B. Shohet, and N. Mohandas. 1986. Molecular cloning of protein 4.1, a major structural element of the human erythrocyte membrane skeleton. Proc. Natl. Acad. Sci. USA. 83:9512-9516.

14. Conboy, J., and N. Mohandas. 1988. Characterization of the gene coding for human erythrocyte protein 4.1. Implications for understanding hereditary elliptocytosis. In Red Blood Cell Membranes. P. Agre and J. C. Parker, editors. Marcel Dekker, Inc., New York. 167-185.

15. Tang, T. K., T. L. Leto, I. Correas, M. A. Alonso, V. T. Marchesi, and E. J. Benz, Jr. 1988. Selective expression of an erythroid-specific isoform of protein 4.1. Proc. Natl. Acad. Sci. USA. 85:3713-3717.

16. Conboy, J., N. Mohandas, G. Tchernia, and Y. W. Kan. 1986. Molecular basis of hereditary elliptocytosis due to protein 4.1 deficiency. N. Engl. J. Med. 315:680-685.

17. Tang, C. J. C., and T. K. Tang. 1991. Rapid localization of membrane skeletal protein 4.1 (EL1) to human chromosome $1 \mathrm{p} 33 \rightarrow \mathrm{p} 34.2$ by nonradioactive in situ hybridization. Cytogenet. Cell. Genet. 57:119.

18. Feddal, S., G. Brunet, L. Roda, S. Chabanis, N. Alloisio, L. Morlé, M. T. Ducluzeau, J. Maréchal, J. Robert, E. J. Benz, Jr., et al. 1991. Molecular analysis of 4.1 ( - ) hereditary elliptocytosis in the French Northern Alps. Blood. 78:21132119.

19. Tang, T. K., K. B. Tam, and S. Chien. 1991. Two RFLPs in the human protein 4.1 gene (EL1). Nucleic Acids Res. 19:6057.

20. Tang, T. K., Z. Qin, T. Leto, V. T. Marchesi, and E. J. Benz, Jr. 1990 Heterogeneity of $\mathrm{mRNA}$ and protein products arising from the protein 4.1 gene in erythroid and nonerythroid tissues. J. Cell Biol. 110:617-624.

21. Conboy, J. G., J. Y. Chan, J. A. Chasis, Y. W. Kan, and N. Mohandas. 1991. Tissue- and development-specific alternative RNA splicing regulates expression of multiple isoforms of erythroid membrane protein 4.1. J. Biol. Chem. 266:8273-8280.

22. Alloisio, N., L. Morlé, E. Dorléac, O. Gentilhomme, D. Bachir, D. Guetarni, P. Colonna, M. Bost, Z. Zouaoui, L. Roda, et al. 1985. The heterozygous form of 4.1 (-) hereditary elliptocytosis ( the 4.1(-) trait). Blood. 65:46-51.

23. Lambert, S., and S. Zail. 1987. Partial deficiency of protein 4.1 in hereditary elliptocytosis. Am. J. Hematol. 26:263-272.

24. McGuire, M., B. L. Smith, and P. Agre. 1988. Distinct variants of erythrocyte protein 4.1 inherited in linkage with elliptocytosis and $\mathrm{Rh}$ type in three white families. Blood. 72:287-293.

25. Féo, C., S. Fischer, J. P. Piau, M. J. Grange, and G. Tchernia. 1980. Première observation de l'absence d'une protéine de la membrane érythrocytaire (bande 4.1) dans un cas d'anémie elliptocytaire familiale. Nouv. Rev. Fr. Hématol. 22:315-325.

26. Tchernia, G., N. Mohandas, and S. B. Shohet. 1981. Deficiency of skeletal membrane protein band 4.1 in homozygous hereditary elliptocytosis: implications for erythrocyte membrane stability. J. Clin. Invest. 68:454-460.

27. Mueller, T. J., and M. Morrison. 1981. Glycoconnectin (PAS2), a membrane attachment site for the human erythrocyte cytoskeleton. In Erythrocyte Membrane 2: Recent Clinical and Experimental Advances. W. C. Kruckenberg, J. W. Eaton, and G. J. Brewer, editors. Alan R. Liss, Inc., New York. 95-112.

28. Alloisio, N., L. Morlé, D. Bachir, D. Guetarni, P. Collonna, and J. Delaunay. 1985. Red cell membrane sialoglycoprotein $\beta$ in homozygous and heterozygous 4.1(-) hereditary elliptocytosis. Biochim. Biophys. Acta. 816:57-62.

29. Sondag, D., N. Alloisio, D. Blanchard, M. T. Ducluzeau, P. Colonna, D. Bachir, C. Bloy, J. P. Cartron, and J. Delaunay. 1987. Gerbich reactivity in 4.1(-) hereditary elliptocytosis and protein 4.1 level in blood group Gerbich deficiency. Br. J. Haematol. 65:43-50.

30. Reid, M. E., Y. Takakuwa, J. Conboy, G. Tchernia, and N. Mohandas. 1990. Glycophorin $C$ content of human erythrocyte membrane is regulated by protein 4.1. Blood. 75:2229-2234.

31. Laemmli, U. K. 1970. Cleavage of structural proteins during the assembly of the head of bacteriophage T4. Nature (Lond.). 227:680-685.

32. Fairbanks, G., T. L. Steck, and D. F. H. Wallach. 1971. Electrophoretic analysis of the major polypeptides of the human erythrocyte membrane. Biochem istry. 10:2606-2617.

33. Alloisio, N., L. Morlé, J. Maréchal, A. F. Roux, M. T. Ducluzeau, D. Guetarni, B. Pothier, F. Baklouti, A. Ghanem, R. Kastally, et al. 1991. Sp $\alpha^{\mathrm{v} / 41}$ : a common spectrin polymorphism at the $\alpha \mathrm{IV}-\alpha \mathrm{V}$ domain junction. Relevance to the expression level of hereditary elliptocytosis due to $\alpha$-spectrin variants located in trans. J. Clin. Invest. 87:2169-2177.

34. Pothier, B., L. Morlé, N. Alloisio, M. T. Ducluzeau, C. Caldani, C. Féo, M. Garbarz, I. Chaveroche, D. Dhermy, M. C. Lecomte, et al. 1987. Spectrin Nice $\left(\beta^{220 / 216}\right)$ : a shortened $\beta$-chain variant associated with an increase of the $\alpha^{1 / 74}$ fragment in a case of elliptocytosis. Blood. 69:1759-1765.

35. Morlé, F., B. Lopez, T. Henni, and J. Godet. 1985. $\alpha$-Thalassaemia associated with the deletion of two nucleotides at position -2 and -3 preceding the AUG codon. EMBO (Eur. Mol. Biol. Organ.) J. 4:1245-1250.

36. Kawasaki, E. S. 1990. Amplification of RNA. In PCR Protocols: A Guide to Method and Applications. M. A. Innis, D. H. Gelfand, J. J. Sninsky, and Y. J. White, editors. Academic Press, Inc., San Diego. 21-27.

37. Frohman, M. A., M. K. Dush, and G. R. Martin. 1988. Rapid production of full-length cDNAs from rare transcripts: amplification using a single gene-specific oligonucleotide primer. Proc. Natl. Acad. Sci. USA. 85:8998-9002.

38. Baklouti, F., J. Maréchal, R. Wilmotte, N. Alloisio, L. Morlé, M. T. Ducluzeau, L. Denoroy, A. Mrad, M. H. Ben Aribia, R. Kastally, et al. 1992. Elliptocytogenic $\alpha^{1 / 36}$ spectrin Sfax lacks 9 amino acids in helix 3 of repeat 4: evidence for the activation of a cryptic 5 '-splice site in exon 8 of spectrin $\alpha$-gene. Blood. 79:2464-2470.

39. Chasis, J. A., L. Coulombel, J. G. Conboy, and N. Mohandas. 1989. Protein 4.1 isoforms are differentially expressed during erythroid maturation. Blood. 74:104a. (Abstr.)

40. Chasis, J. A., J. Conboy, G. Tchernia, A. Kabra, R. Winardi, and N. Mohandas. 1991. Expression of protein 4.1 in non-erythroid cells of individual with 4.1 deficient erythrocytes through use of alternative translation initiation site (s). Clin. Res. 39:269a. (Abstr.)

41. Conboy, J., J. A. Chasis, R. Winardi, G. Tchernia, Y. W. Kan, and N. Mohandas. 1991. Tissue-specific deficiency of protein 4.1 as a consequence of usage of an alternative translation initiation site. Blood. 78:365a. (Abstr.)

42. Conboy, J., S. Marchesi, R. Kim, P. Agre, Y. W. Kan, and N. Mohandas. 1990. Molecular analysis of insertion/deletion mutations in protein 4.1 in elliptocytosis. II. Determination of molecular genetic origins of rearrangements. $J$. Clin. Invest. 86:524-530.

43. Conboy, J. G., R. Shitamoto, M. Parra, R. Winardi, A. Kabra, J. Smith, and $N$. Mohandas. 1991. Hereditary elliptocytosis due to both qualitative and quantitative defects in membrane skeletal protein 4.1. Blood. 78:2438-2443.

44. Pirastu, M., G. Saglio, J. C. Chang, A. Cao, and Y. W. Kan. 1984. Initiation codon mutation as a cause of $\alpha$-thalassemia. J. Biol. Chem. 259:1231512317.

45. Moi, P., F. E. Cash, S. A. Liebhaber, A. Cao, and M. Pirastu. 1987. An initiation codon mutation (AUG $\rightarrow$ GUG) of the human $\alpha 1$-globin gene: Structural characterization and evidence for a mild thalassemic phenotype. J. Clin. Invest. 80:1416-1421.

46. Baserga, S., and E. J. Benz, Jr. 1988. Nonsense mutations in the human $\beta$-globin gene affect mRNA metabolism. Proc. Natl. Acad. Sci. USA. 85:20562060. 